\title{
Validity of recall absent schoolchildren to free eye health projects
}

\author{
Validade da reconvocação de escolares faltosos a exame ocular gratuito
}

Regina Noma ${ }^{1}$, Regina de Souza Carvalho², Newton Kara-José ${ }^{3}$

\begin{abstract}
Purpose:To analyze the results of recall absent schoolchildren to eye health projects. Methods: Cross-sectional study. Visual screening was performed in schoolchildren attending $1^{\text {st }}$ to $4^{\text {th }}$ grades at public schools, from 7 to 10 years-old, to select and forward to complete ophthalmic evaluation. The projects were performed during weekends, at a public school, in the same municipality. Free transportation, food and eyeglasses were offered. A second opportunity of examination was offered to the students who were absent from the first call, with the same facilities.

Results: 51,509 schoolchildren had their vision tested, 14,651 (28.4\%) were referred for ophthalmic examination. Of these, 8,683 (59.3\%) attended the first call, 2,228 (37.3\%) attended the recall and $25.5 \%$ of parents did not take their children to ophthalmic examination. The need for eyeglasses for children who attended the examination was $23.8 \%$ and $32.0 \%$ in the first opportunity and recall, respectively. The recall increased the coverage in $15.2 \%$ (59.3\% to $74.5 \%$ ).

Conclusion: An expressive number of parents (25.5\%) did not bring their children to be examined, even at a second opportunity of exam. The facilities offered: access, free examination, transportation and glasses. Children who were absent in the first opportunity and appeared at recall had a greater need for eyeglasses. Recall increased the coverage in $15.2 \%$ (59.3\% to $74.5 \%$ ) and it is not recommended when financial resources are limited.
\end{abstract}

Keywords: Medical examination; Vision, ocular; Visual acuity; School health; Child health (Public Health); Health education; Health programs and plans

\section{RESUMO}

Objetivo: Analisar os resultados da reconvocação de escolares faltosos a projeto de saúde ocular.

Métodos: Estudo transversal descritivo. Escolares de 7 a 10 anos de $1^{\underline{a}}$ a $4^{\underline{a}}$ séries do en sino fundamental foram triados nas escolas eencaminhados para exame oftalmológico completo. Os exames foram realizados durantefins desemana, em escola pública. Foram oferecidos transporte, alimentação e óculos gratuitos. Uma segunda oportunidade de exame foi oferecida aos faltosos, com as mesmas facilidades.

Resultados: Foram triados 51.509 escolares e encaminhados 14.651 (28,4\%). Compareceram 8.683 crianças $(59,3 \%)$ na primeira convocação. Os escolares faltosos (5.968) foram reconvocadose $2.228(37,3 \%)$ compareceram àreconvocação, sendo que $25,5 \%$ dospaisnão levaram seus filhos para exame. Anecessidade de óculos, para crianças que compareceram ao exame, foide $23,8 \%$ e 32,0\%, na primeira convocação ereconvocação, respectivamente. A reconvocação aumentou a cobertura do projeto em $15,2 \%$ (59,3\% to $74,5 \%$ ).

Conclusão: Um número expressivo de pais (25,5\%) não leva seus filhos para exame, apesar das facilidades oferecidas de acesso, transporte, exame e óculos gratuitos. A necessidade de óculos foi maior nos escolares que compareceram à reconvocação que na primeira convocação. A reconvocação aumentou a cobertura de 59,3 para 74,5\% e não está indicada quando os recursos financeiros são limitados.

Descritores: Exames médicos; Visão ocular; Acuidade visual; Saúde escolar; Saúde da criança; Educação em saúde; Planos e programas de saúde

\section{INTRODUCTION}

Correction of refractive error is still a big challenge with regards to promoting worldwide eye care ${ }^{(1)}$. In 2004, World Health Organization (WHO) estimated that 314 million people are visually impaired in the world, while 153 million people are affected by uncorrected refractive error ${ }^{(1)}$. Uncorrected refractive error is the main cause of low vision and second cause of blindness, after cataract ${ }^{(2)}$. Without proper optical correction, 153 million people miss opportunities, are disqualified to work and experience economical and social consequences ${ }^{(3)}$.

The losses with regards to children learning, intellectual development and socialization are immeasurable. It is estimated that 12.8 million children between 5 and 15 years old are impaired due to lack of or inappropriate optical correction, a global prevalence of $0.96 \%{ }^{(1)}$. Even in a developed country like the United States, visual disorders are the fourth most common cause of disability and the most prevalent handicapping condition in childhood ${ }^{(4)}$. In Brazil, it is estimated that $6 \%$ of preschool children need optical correction ${ }^{(5)}$
Actions to prevent blindness and reduce low vision due to refractive error include mass screening for visual acuity, professionals to perform refractive examinations and provision of affordable eyeglasses ${ }^{(6,7)}$. Despite being a rapid procedure at low costs, the lack of optical correction remains as an important problem ${ }^{(7-10)}$.

In Brazil, community projects aimed at detecting visually impaired elementary schoolchildren have been performed for several decades. The community campaigns "Eye-to-Eye" were created to detect barriers to optical correction procedures, as well as to demonstrate their feasibility by offering access to ophthalmic examination and eyeglasses to children attending $1^{\text {st }}$ to $4^{\text {th }}$ grades at public schools. Campaigns "Eye to Eye" (1998-2001) were one of the largest ocular public health projects in the world, attending more than 14 million students $s^{(7)}$.

One of the barriers to coverage of theses project is the absenteeism ${ }^{(7)}$. Since the 70 s, several studies have reported high rates of non-attendance to community campaigns, ranging from 31.2 to $68.7 \%{ }^{(10-15)}$. The main difficulties reported by defaulters are lack of transportation, lack of orientation and loss of working day ${ }^{(7,11,16)}$.
Submitted for publication: February 16, 2011

Accepted for publication: November 28, 2011

Study carried out at the Departamento de Oftalmologia da Universidade de São Paulo - USP - São Paulo (SP), Brazil.

Physician, Department of Ophthalmology, Universidade de São Paulo - USP - São Paulo (SP), Brazil. 2 Pedagogue, Universdade de São Paulo - USP - São Paulo (SP), Brazil.

${ }^{3}$ Professor, Department of Ophthalmology, Universidade de São Paulo - USP - São Paulo (SP), Brazil.
Funding: No specific financial support was available for this study.

Disclosure of potential conflicts of interest: R.Noma, None; R.S.Carvalho, None; N.Kara-José, None. Correspondence address: Regina Noma. Av. Antonio Carlos Comitre, 510 - cj. 81- Sorocaba (SP) 18047-620 - Brazil - E-mail: reginanoma@hotmail.com 
Recently, some campaigns include facilities of transportation, examinations performed at places near schools and during weekends, in order to increase the attendance $(7,11,16)$. The students could have some difficulties in the campaign day and offering them a second opportunity of exam is an option that needs to be assessed. Quite a few projects make a recall of defaulters ${ }^{(11,16)}$, without any analysis of effectiveness of this procedure.

In this study, there were two calls (first call and recall of absentees). The analysis of results of the recall is important to improve the project methodology in order to solve operational issues and attain better results.

The purpose of this study is to study the results of recall absent schoolchildren to the eye care community projects, aiming at improving the efficiency of these actions.

\section{METHODS}

In 2006 and 2007, a transversal study was conducted with students attending 61 municipal public schools in Guarulhos. The target population was composed by all the 51,509 students, whose age ranged from 7 to 10 years old, enrolled in $1^{\text {st }}, 2^{\text {nd }}, 3^{\text {rd }}$ and $4^{\text {th }}$ grades of the $1^{\text {st }}$ cycle of elementary school. Guarulhos belongs to the metropolitan area of São Paulo, located $17 \mathrm{~km}$ from the capital city. It is the $12^{\text {th }}$ most populated city of the country and gross national product (GNP) per capita of R\$22,202.00 ( $\cong$ US\$12,677.44/US\$ = 1.7513 18/08/10); Brazil R\$15,240.00/2008 ( $\cong$ US\$ 8,702.11). In Guarulhos, $97.9 \%$ of the children are enrolled at and attend school ${ }^{(17)}$.

The students'visual acuity was screened by the teachers at school. The criteria for referral were: a) visual acuity equal or lower than 0.7 in one eye or difference of vision between the eyes of at least 2 lines; b) evident strabismus; c) asthenopia; d) use of eyeglasses ${ }^{(18)}$.

Referred students were scheduled by grades and attended at a primary care center in the same municipality.

On the campaign day, a new visual acuity screening and assessment of extrinsic ocular motility were done by ophthalmologists. Distance visual acuity (without and with glasses for those wearing them at the time of the examination) was measured with $\mathrm{E}$ chart at $5 \mathrm{~m}$. Those with uncorrected visual acuity better than 0.7 in each eye with no signs of asthenopia and absence of strabismus were dismissed (false-positive). The remaining students were referred to a complete ophthalmologic examination. Examination included visual acuity testing, ocular motility, biomicroscopy, auto-refraction, cycloplegic refraction and fundus examination. Cycloplegia was induced by three drops of $1 \%$ cyclopentolate, administered 5 minutes apart.

The project was composed of two parts: first call and recall absentees.

The eye health care services were carried out during weekends (Saturday and Sunday) and the intermission between first call and recall absentees was less than 2 months. Free transportation and free lunch were provided on the examination days and the prescription eyeglasses were donated.

The criteria for prescription of glasses were based on cycloplegic refraction (hyperopia > +3.00 DE; myopia > -0.75 DE; astigmatism $>-0.75$ DC); improvement in cycloplegic visual acuity and visual complaints ${ }^{(19)}$.

The study was approved by the Ethics Committee for Research Projects/ Investigational Review Board of the Clinical Board of Hospital das Clínicas and the School of Medicine, University of São Paulo/SP (no 0557/07). Informed consent form had been obtained from each child's parent/guardian.

The data was verified for entry with EpiData Software (version 3.0) and analyzed through the Statistical Package for Social Sciences (SPSS) software 15.0. The admitted significant statistical level was of $5 \%(p \leq 0.05)$.

\section{RESULTS}

The population was composed of 51,509 schoolchildren. After visual screening, 14,651 (28.4\%) students were referred to ophthalmic examination of which 8,683 (59.3\%) answered to the first call. As for the 5,968 recalled students, 2,228 (37.3\%) attended the recall (Figures 1 and 2). The recall resulted in a coverage increment of 15.2\% $(59.3 \%$ to $74.5 \%$ ). The total amounts to 10,911 students (74.5\% of those referred to examination) had their eyes examined (Table 1).

Of the 14,651 eligible subjects, 10,911(74.5\%) aged 7-10 years participated, including 5,540 (50.7\%) girls and 5,371 (49.2\%) boys. The distribution of age was: 2,910 (26.7\%) were 7; 2,774 (25.4\%) were 8; 2,537 (23.3\%) were 9 and 2,690 (24.6\%) were 10 years old.

The need for eyeglasses was statistically higher in the children who attended the recall than those who attended at first call $(p<0.001)$ (Table 1). There was no statistically difference between gender and prescribed eyeglasses.

\section{DISCUSSION}

The problem of visual impairment in childhood is significant, with low-cost solution, but involves several barriers such as lack of parental involvement. There is an expressive number of parents who do not bring their children to be examined (Figure 2), despite the facilities offered.

There were 51,509 students screened by their teachers; 14,651 (28.4\%) were referred to ophthalmic examination and 8,683 (59.3\%) students attended the first call. There were 5,968 recalled defaulters, only 2,228 (37.3\%) appeared. Absenteeism at the first call was $40.7 \%$ and higher at recall (62.7\%), as shown in figure 1.

The barriers to the utilization of eye services have already been studied ${ }^{(20-22)}$, however, this is the first study conducted to assess coverage increase by means of recalling absentees and determining whether or not this group requirement for eyeglasses is lower.

The main reasons for no-shows to eye health care services are:

- school faulty orientation with regards to day, time, and locality where the examination will take place;

- financial issues related to transportation to the service venue; long distances from home to the consultation venue;

- parents who are unable to find someone to stay with the younger children;

- meteorological changes;

- other service options (health insurance contract, private medical assistance);

- child or family member illness;

- unavailability of parents and relatives, who are working or absent, to bring the child to the campaign;

- absent-minded guardian;

- campaign lack of credibility;

- denial with regards to child's low vision $(7,11,15,16)$

- Other determining factors such as lack of consciousness (awareness and understanding) of the importance of ophthalmic examinations, fear, fatalism ${ }^{(20,22-24)}$.

Another possibility for missing the first call is that these students could have fewer complaints and visual symptoms (lower need for optical correction). However, the percentage of children who required eyeglasses was statistically higher in the recall group $(p<0.001)$.

The validity of conducting a second call must be assessed by the following issues: resources availability; health planning priorities; goal of the project coverage. The goal of public health care actions is to provide services to a large number of students with the existing resources. By taking into account the cost of each stage of the project and the percentage of children who were benefited, it is suggested that a larger attendance be achieved at the first call, in an attempt to benefit a higher number of children and avoid the relatively high recall costs. 


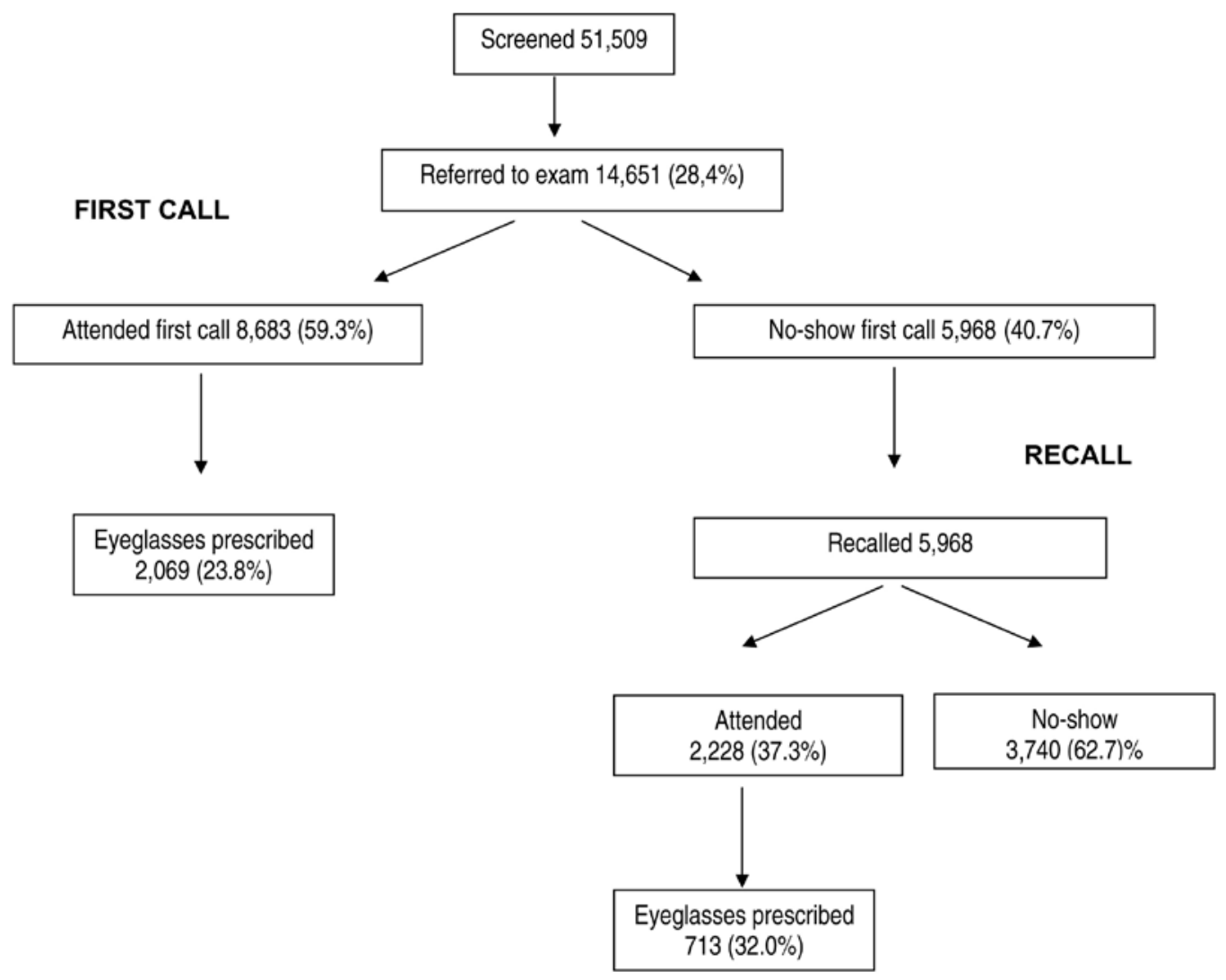

Figure 1. Attendance and eyeglasses prescribed at first call and recall - Campaign “Eye to Eye" Guarulhos 2006 and 2007.

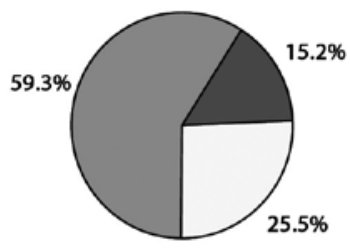

口Attended on first call

口Attended upon recall

$\square$ No show

Figure 2. Service coverage of the Campaign "Eye to Eye" Guarulhos, 2006 and 2007.

Table 1. Percent of prescribed eyeglasses according to call - Campaign "Eye to Eye" Guarulhos 2006 e 2007

\begin{tabular}{|c|c|c|c|c|c|c|c|}
\hline \multirow[b]{3}{*}{ Eyeglasses } & \multicolumn{4}{|c|}{ Call } & & & \\
\hline & \multicolumn{2}{|c|}{ First } & \multicolumn{2}{|c|}{ Recall } & \multicolumn{2}{|c|}{ Total } & \multirow[b]{2}{*}{$p$ value } \\
\hline & $n$ & $\%$ & $n$ & $\%$ & $\mathbf{n}$ & $\%$ & \\
\hline Yes & 2.069 & 23.8 & 713 & 32 & 2.782 & 25.5 & \multirow{3}{*}{$<0.001$} \\
\hline No & 6.614 & 76.2 & 1.515 & 68 & 8.129 & 74.5 & \\
\hline Total & 8.683 & 100.0 & 2.228 & 100 & 10.911 & 100.0 & \\
\hline
\end{tabular}

The campaign operational design ${ }^{(25)}$ was similar for both first call and recall, since it was necessary to schedule another appointment, provide transportation and food, prepare the equipment and gather personnel for examination. The entire structure had to be assembled again, but the number of students who appeared at recall was too low which resulted in a higher service cost per capita. The first call was four times more effective in terms of students benefited. Thus, higher priority should be given to investments in advertisement of community projects campaigns and in the community education.

The first call reached $59.3 \%$ and recall $37.3 \%$ of students. So recall increased the campaign coverage in $15.2 \%$ - from $59.3 \%$ to $74.5 \%$ (Table 1). The total number of 8,683 schoolchildren attended at the first call was increased to 10,911. The recall was much less efficient than the first call.

Using the health system involves search behavior and access to the existing services ${ }^{(22,26,27)}$. The eye-care services should be available, accessible, affordable and acceptable to the people ${ }^{(28)}$. This study reveals evident lack of involvement of the community and unawareness with regards to the importance of visual examination. It's a behavioral problem as observed previously in Brazil, for cataract and glaucoma treatment ${ }^{(29,30)}$. Given the parents' behavior towards free examinations and suitable health care services, it can be assumed that parents' initiative to spontaneously bring their children to be examined is less probable.

Evaluation is essential to the expansion of eye health promotion, in order to provide information and feedback to make improvements in future activities. While the ultimate goal is improved eye health, it is useful to incorporate intermediate indicators, such as increased awareness, behavior change, skills, self efficacy, coverage and quality of services, and adoption of specific policies.

As a result of parents' refusal to accept a presumed visual problem, the routine examination becomes even more important at the time the child starts attending school, not only to detect refractive errors, but also due to its educational role within the community. It is necessary to educate the population with respect to adoption of eye health promoting behaviors, changing health concepts and preventing ocular diseases $(22,27,31)$. 
The recall of absent students is indicated only if the first call was done for all school grades. Absent schoolchildren may be recalled whenever another campaign is organized.

\section{CONCLUSION}

Under the conditions of this study, recall absent students to ophthalmic examination had a low impact in the increase of health service coverage (15.2\%) and it is not recommended when financial resources are limited. Schoolchildren who missed the first call and attended the recall had a greater need for eyeglasses. A significant number of parents $(25.5 \%)$ do not take their children to have an ophthalmic examination, despite the facilities offered.

\section{REFERENCES}

1. Resnikoff S, Pascolini D, Mariotti SP, Pokharel GP. Global magnitude of visual impairment caused by uncorrected refractive errors in 2004. Bull World Health Organ. 2008 86(1):63-70. Comment in Bull World Health Organ. 2008;86(8):B-C; author reply C.

2. Eduardo Leite Arieta C, Nicolini Delgado AM, José NK, Temporini ER, Alves MR, de Carvalho Moreira Filho D. Refractive errors and cataract as causes of visual impairment in Brazil. Ophthalmic Epidemiol. 2003;10(1):15-22.

3. Smith TS, Frick KD, Holden BA, Fricke TR, Naidoo KS. Potential lost productivity resulting from the global burden of uncorrected refractive error. Bull World Health Organ. 2009;87(6):431-7.

4. Gerali PS, Flom MC, Raab EL; National Society to Prevent Blindness. Report of children's vision screening task force. Schaumburg: National Society to Prevent Blindness; 1990

5. Costa MN, Kara-José N, Rueda G, Pereira VL, Macchiaverni Filho N, Fávero M. Estudo da incidência de ambliopia, estrabismo e anisometropia em pré-escolares. Arq Bras Oftalmol. 1979;42(6):249-52.

6. Pizzarello L, Abiose A, Ffytche T, Duerksen R, Thulasiraj R, Taylor H, et al. VISION 2020: The Right to Sight: a global initiative to eliminate avoidable blindness. Arch Ophthalmol. 2004;122(4):615-20. Review.

7. Carvalho RS, Kara-José N, Gonçalves ER. Avaliação das Campanhas de Prevenção e Reabilitação Visual Olho no Olho - 1998 a 2001. In: Kara-José N, Gonçalves ER, CarvaIho RS. "Olho no Olho - Campanha Nacional de Prevenção e Reabilitação Visual do escolar". Rio de Janeiro: Cultura Médica; 2006. p. 119-29.

8. Dandona R, Dandona L. Refractive error blindness. Bull World Health Organ. 2001: 79(3):237-43.

9. Thylefors B. A global initiative for the elimination of avoidable blindness. Community Eye Health. 1998;11(25):1-3.

10. Kara-José N, Ferrarini ML, Temporini ER. Avaliação do desenvolvimento do plano de oftalmologia sanitária escolar em três anos da sua aplicação no Estado de São Paulo. Arq Bras Oftalmol. 1977;40(1):9-15.

11. Alves MR, Temporini ER, Kara-José N. Atendimento oftalmológico de escolares do sistema público de ensino no município de São Paulo: aspectos médico-sociais. Arq Bras Oftalmol. 2000;63(5):359-63.
12. Castro RS. Triagem visual e assistência oftalmológica em pré-escolares da cidade de Limeira (SP), 1995 [tese]. Campinas: Faculdade de Ciências Médicas da Universidade Estadual de Campinas; 1997.

13. Kara-José N, de Carvalho KM, Caldato R, Pereira VL, de Oliveira AM, Fonseca Neto JC. Atendimento de amblíopes e prevalência na população pré-escolar, Campinas, São Paulo, Brasil. Bol Oficina Sanit Panam. 1984;96(1):31-7.

14. Constanti FU, Costa MS, Salgado MB, Bastos CLFM, Benchimol E. Avaliação das alterações oculares encontradas na aplicação do projeto de oftalmologia sanitária escolar. Rev Bras Oftalmol. 1989;48(1):39-42.

15. Abud AB, Ottaiano JAA. Aspectos socioeconômicos que influenciam no comparecimento ao exame oftalmológico de escolares com alterações visuais. Arq Bras Oftalmol. 2004:67(5):773-9.

16. Cavalcante SM, Kara José $N$, Temporini ER. Percepção de pais de escolares da $1^{\underline{a}}$ série do ensino fundamental a respeito da campanha "Olho no Olho" 2000, na cidade de Maceió - Alagoas. Arq Bras Oftalmol. 2004;67(1):87-91.

17. Instituto Brasileiro de Geografia e Estatística - IBGE. Educação no Brasil. 2003. Disponível em: http://www.ibge.gov.br/ibgeteen/pesquisas/educacao.html.

18. Carvalho RS, Temporini ER, Kara-José N. Assessment of visual health campaign activities at schools: teachers' perception. Arq Bras Oftalmol. 2007;70(2):239-45.

19. Conselho Brasileiro de Oftalmologia. Ofício CBO / CP-001-01: Ref. "Prescrição de óculos / Campanha Olho no Olho". 2000.

20. Donoghue M. People who don't use eye services: 'making the invisible visible'. Community Eye Health. 1999;12(31):36-8.

21. Fletcher AE, Donoghue M, Devavaram J, Thulasiraj RD, Scott S, Abdalla M, et al. Low uptake of eye services in rural India: a challenge for programs of blindness prevention. Arch Ophthalmol. 1999:117(10):1393-9.

22. Noma R, Carvalho RS, José NK. Why are there defaulters in eye health projects? Clinics (Sao Paulo). 2011;66(9):1585-9.

23. He M, Xu J, Yin Q, Ellwein LB. Need and challenges of refractive correction in urban Chinese school children. Optom Vis Sci. 2005;82(4):229-34.

24. Odedra N, Wedner SH, Shigongo ZS, Nyalali K, Gilbert C. Barriers to spectacle use in Tanzanian secondary school students. Ophthalmic Epidemiol. 2008;15(6):410-7.

25. Carvalho RS, José NK, Arieta CEL, Castro RS. Campanhas comunitárias: conceitos básicos. In: José NK, Gonçalves ER, Carvalho RS, editores. Olho no olho. Rio de Janeiro: Cultura Médica; 2006. p.7-16.

26. Shengelia B, Murray $C J$, Adams OB. Beyond access and utilization: defining and measuring health system coverage. In: Murray CJ, Evans DB, editors. Health system performance assessment: debates, methods and empiricism. Geneva: World Health Organization; 2003. p.221-34.

27. Hubley J, Gilbert C. Eye health promotion and the prevention of blindness in developing countries: critical issues. Br J Ophthalmol. 2006;90(3):279-84.

28. Dandona R, Dandona L. Review of findings of the Andhra Pradesh Eye Disease Study: policy implications for eye-care services. Indian J Ophthalmol. 2001;49(4):215-34

29. Arieta CEL, Taiar A, José NK. Utilização e causas de suspensão de intervenções cirúrgicas oculares em centro cirúrgico ambulatorial universitário. Rev Assoc Med Bras (1992). 1995;41(3):233-5.

30. Silva LR, Paula JS, Rocha EM, Rodrigues MLV. Fatores relacionados à fidelidade ao tratamento do glaucoma: opiniões de pacientes de um hospital universitário. Arq Bras Oftalmol. 2010;73(2):116-9.

31. Candeias NMF. Conceitos de educação e de promoção em saúde: mudanças individuais e mudanças organizacionais. Rev Saúde Pública. 1997;31(2):209-13. 